(C) Портян М. О., 2018 p.

http://orcid.org/0000-0001-9399-868X

DOI: $10.34142 / 23128046.2019 .46 .08$

М. О. Портян

\title{
ФОРМУВАННЯ ПРОЕКТУВАЛЬНОЇ КОМПЕТЕНТНОСТІ МАЙБУТНІХ УЧИТЕЛІВ ПОЧАТКОВОЇ ШКОЛИ І ВИХОВАТЕЛІВ ЗАКЛАДІВ ДОШКІЛЬНОЇ ОСВІТИ
}

Стаття присвячена визначенню рівнів сформованості проектувальної компетентності майбутніх учителів початкової школи $і$ вихователів на констатувальному етапі педагогічного експерименту. Проведено науковий аналіз суті поняття «проектувальна компетентність», визначено ї̈ складові. У прочесі дослідження визначено компоненти сформованості проектувальної компетентності майбутніх учителів початкової иколи $i$ вихователів: мотиваційно-ціннісний, когнітивний та діяльніснорефлексійний. Мотивачійно-ціннісний компонент сформованості передбачає наявність у майбутніх учителів початкової школи і вихователів мотивації до навчального проектування, когнітивний - обізнаність зі знаннями, необхідними для сформованості проектувальної компетентності та набуття комплексу відповідних умінь $i$ навичок, щзо забезпечують оптимізацію освітнього процесу, діяльнісно-рефлексійний - оволодіння вміннями проектувати освітній процес у закладах дошкільноӥ освіти та початковій школі, корекиія ц̧ього процесу.

До вмінь, які сприяють сформованості проектувальної компетентності віднесено: аналітичні, гностичні, дослідницькі, діагностичні, креативні та рефлексивні. Формування відповідних умінь відбувалося під час вивчення курсів "Методика викладання педагогічних дисциплін», "Організація і управління педагогічним прочесом у закладах дошкільної освіти», «Загальна педагогіка». Для перевірки сформованості проектувальної компетентності майбутніх учителів початкової иколи $i$ вихователів за визначеними у статті критеріями схарактеризовано методи дослідження. Результати проведеного етапу педагогічного експерименту дали підстави констатувати переважно середній та низький рівні сформованості проектувальної компетентності майбутніх учителів початкової школи і вихователів. Наступними напрямами наукових розвідок із представленої проблеми автор вважає за необхідність теоретично обгрунтувати технологію формування проектувальної компетентності та реалізувати ї̈ в процесі підготовки майбутніх учителів початкової школи $i$ вихователів. 
Ключові слова: майбутні вчителі початкової школи, вихователі, підготовка, проектувальна компетентність, професійна готовність, педагогічний експеримент.

Portyan M. O. Formation of project competence of future primary school teachers and educators of preschool education institutions. The article is devoted to determining the levels of formation of project competence of primary school future teachers and educators at the stage of the pedagogical experiment. A scientific analysis of the essence of the concept of "project competence» was carried out, its components were determined. In the course of the research, the components of the designing competence of future primary school teachers and educators are determined: motivational-value, cognitive and activity-reflective. The motivational-value component of the formation implies the presence of motivation for future primary school teachers and educators for training in project activity, the cognitive - knowledge that are necessary for the development of project competence and the acquisition of a set of relevant skills and abilities that provide optimization of the educational process, the activity-reflective - mastery of skills to design educational process in institutions of preschool education and elementary school, correction of this process.

The abilities that contribute for the formation of project competence are classified as: analytical, gnostic, research, diagnostic, creative and reflexive. Formation of the appropriate skills took place during the study such courses as "Methodology of pedagogical disciplines teaching», "Organization and management of pedagogical process in institutions of preschool education», "General pedagogy». For verification of the formation of project competence of primary school future teachers and educators, we defined the criteria in the article and characterized the research methods. The results of the conducted stage of the pedagogical experiment gave grounds to ascertain mainly the middle and low level of formation of project competence of primary school future teachers and educators. The following directions of scientific developments on the presented problem, authors consider the necessity to theoretically substantiate the technology of formation of project competence and to realize it in the process of preparation of primary school future teachers and educators.

Keywords: future primary school teachers, educators, preparation, project competence, professional readiness, pedagogical experiment.

Вступ. Поступове входження вищої національної освіти до європейського освітнього простору та концептуальні зміни у структурі й змісті вітчизняної загальної середньої освіти зумовлюють потребу в якісному оновленні підготовки майбутніх учителів, що базується на положеннях законів України «Про освіту» (2017), «Про вищу освіту» (2014), Галузевої 
концепції розвитку неперервної педагогічної освіти (2013), Концепції розвитку освіти України на період 2015-2025 pр. (2014), Указі Президента України «Про національну стратегію розвитку освіти в Україні на період до 2021 року» (2013).

За останні роки відбулися суттєві зміни в системі початкової школи: затверджені нові Державні стандарти початкової освіти, створені варіанти нових навчальних програм і підручників, визначені об’єкти, функції, види контролю та критерії оцінювання навчальних досягнень молодших школярів. Тому важливою $є$ переорієнтація підготовки майбутнього вчителя початкової школи 3 просвітництва до ролі дослідника, агента змін, здобувача ефективних засобів навчально-виховної роботи в інтересах дитини, про що наголошується в Концепції «Нова українська школа» (2016).

Аналіз основних досліджень і публікацій, в яких започатковано розв'язання даної проблеми показав, що успішні досягнення поставлених цілей і вся подальша професійна діяльність майбутнього вчителя початкової школи i вихователя неможливі без високого рівня сформованості проектувальної компетентності, оскільки для здійснення професійної діяльності фахівцю необхідно постійно проектувати свої дії, володіти прийомами професійного, проектувального мислення: плануванням, аналізом, прогнозуванням, моделюванням тощо.

На вчителя початкової школи та вихователя закладу дошкільної освіти покладено відповідальність розвивати творчу особистість дитини, виявляти іiї здібності, створювати сприятливу атмосферу на уроках, формувати систему морально етичних цінностей. Діти потребують учителів та вихователів, які будуть їх розуміти і проектувати їхню діяльність. Однак, проведені нами опитування 112 студентів випускних курсів, а також 25 викладачів педагогічних ЗВО засвідчили, що сучасний рівень професійної підготовки майбутніх учителів початкової школи має значні недоліки щодо формування у них проектувальної компетентності. Зокрема, близько 79 \% опитаних недостатньо усвідомлюють суть поняття «проектувальна компетентність», 
його закономірності та психолого-педагогічні особливості навчального проектування; 79 \% респондентів відчувають труднощі при формуванні не лише професійних знань, умінь i навичок, а й умінь конструювати та проектувати уроки та заняття для дітей. У цьому контексті набуває актуальності проблема формування проектувальної компетентності майбутніх учителів початкової школи та вихователів.

При проведенні дослідження ми спираємось на теоретикометодологічні та психолого-педагогічні засади формування проектувальної компетентності фахівців, розкриті науковцями. Так, В. Гриньова (2011), К. Юр’єва та О. Тіщенко (2014) у своїх наукових доробках обгрунтували теоретичні основи формування професійної компетентності, іiі суть, види тощо; у роботі О. Жерновникової (2015) визначено дидактичні засади підготовки майбутніх учителів до навчального проектування; концептуальні положення педагогічного проектування висвітлено в працях Н. Брюханової (2010, 2012); методологічне підгрунтя проектування системи дистанційного навчання розроблено Н. Буркіною (2009) та В. Докучаєвою (2007), а загальні принципи - М. Колядою (2006); технологічну основу проектування освітнього процесу запропоновано І. Зязюном (2010), М. Гриньовою (2012), Т. Гончаренко (2011), В. Шарко (2011), О. Кравцем (2013); передумови проектування освітнього середовища майбутніх учителів проаналізовано О. Коханко (2009), О. Солом'яним (2006), О.Ярошинською (2014), а освітнього середовища учнів - О. Коберником (1995), А. Цимбалару (2013). Iз зарубіжних учених проектувальну компетентність досліджували К. Куін (2002).

Вважаємо, що природа компетентності така, що вона є продуктом освіти; наслідком саморозвитку людини, його особистісного зростання; наслідком самоорганізації та узагальнення особистісного та діяльнісного досвіду. Для того, щоб виявити основні характеристики проектувальної компетентності майбутніх учителів початкової школи та вихователів закладів 
дошкільної освіти, необхідно розглянути ряд наукових понять, які допоможуть розкрити суть і специфіку даного феномена та його структуру.

Мета статті - схарактеризувати результати сформованості проектувальної компетентності у майбутніх учителів початкової школи та вихователів закладів дошкільної освіти.

На основі визначеної мети, нами поставлені такі завдання:

- Визначити суть поняття «проектувальна компетентність» та іiі складові.

- На основі проведеного аналізу охарактеризувати компоненти проектувальної компетентності.

- Визначити критерії та рівні сформованості проектувальної компетентності.

Методи дослідження. Для досягнення мети та виконання завдань дослідження було застосовано такі методи: теоретичні - аналіз психологопедагогічної літератури 3 метою визначення ступеня наукової розробки проблеми; класифікація, узагальнення, порівняння - для визначення провідних понять дослідження; емпіричні - педагогічний експеримент 3 метою перевірки сформованості проектувальної компетентності у майбутніх учителів початкової школи та вихователів закладів дошкільної освіти.

Результати. У контексті розвитку НУШ професіоналізм майбутнього вчителя початкової школи та вихователя визначається його здатністю до діагностики, моделюванню освітнього процесу, зокрема i вміннями моделювати та проектувати уроки й заняття, виховні заходи, навчальні програми тощо.

Ключовими поняттями досліджуваної проблеми $є$ «проект», «проектування», «проектувальні уміння», співвідношення понять «проектування», «прогнозування», «моделювання» і «вміння».

В українському педагогічному словнику С. Гончаренка підкреслюєься, що проектувати - це «задумати, загадати,.., передбачити до виконання, скласти для цього записку» (Гончаренко, 1997). Н. Брюханова визначає 
педагогічне проектування як одну з функцій будь-якого педагога, що є не менш значущою, ніж організаторська, гностична або комунікативна (Брюханова, 2012). А. Цимбалару розглядає проектування як одну із стадій підготовки до уроку, яка закінчується створенням програми управління пізнавальною діяльністю учнів (Цимбалару, 2013).

3 огляду на вище зазначене суть поняття «проектування» розглядаємо як орієнтацію на майбутнє (без урахування минулого), ідеальне переосмислення та практичне втілення того, що можливо, i того, що має бути; один із способів інноваційної діяльності, який використовує соціокультурні механізми конструювання i реконструювання соціальних об'єктів.

Проектування як вид діяльності завжди спрямоване на забезпечення ефективності процесу професійної підготовки та на формування професійної компетентності у певній галузі. Усяке проектування обумовлено потребою розгляду актуальної, професійної проблеми, має творчий характер, грунтується на мотивації, має ціннісні орієнтації, знання, вміння та навички, спрямоване на професійний досвід і на особистісну і професійну рефлексію.

Результатом проектування виступає модель певного, професійного об’єкта, в основі якого лежить новий спосіб вирішення професійної проблеми і передбачає різноманітні варіанти використання даної моделі на різних етапах: визначення цілей проектування, опис у конкретних деталях i вимірювальних параметрах очікуваного результату; оволодіння змістовним аспектом проектування в контексті майбутньої професійної діяльності (знання, вміння, навички, прийоми, інформаційна подача матеріалу, розуміння педагогічної системи зв'язків 3 iї елементами професійно діяльності); виявлення поетапності структури професійної діяльності, спрямованої на оптимальне досягнення мети проекту; представлення професійного досвіду опанування системи пізнавальних завдань; вибір адекватних методів, форм і засобів реалізації проектної діяльності; виявлення логіки проектної діяльності з метою накопичення досвіду на основі проекту; 
контроль та вимірювання якості проекту через операції професійної рефлексії; індивідуальна корекція проектної діяльності через взаємодію на основі суб’ єктних відносин.

Так, О. Жерновникова (2015) в конструктивно-проектній діяльності визначає три етапи: педагогічне моделювання (створення моделей); педагогічне проектування (створення проекту); конструктивно-проектна діяльність (власне проект, більш деталізований, конкретизований, наближений до реальних умов). Розглядаючи моделювання як один із етапів проектування, дослідниця запропонувала організаційний алгоритм моделі проекту, але невирішеним залишається питання керованості процесу проектування, його оцінки і можливості підвищення ефективності.

Зі сказаного вище випливає, що проектувальна компетентність майбутнього вчителя початкової школи та вихователя закладу дошкільної освіти розглядається як: здатність, спрямована на створення проекту; науково-практичний метод вивчення i перетворення дійсності (метод практико-орієнтованої науки); форма породження, характерна для технологічної та управлінської культури.

Для того, щоб здійснювати проектування, тобто сформувати власну проектувальну компетентність, у майбутнього вчителя мають бути розвинені певні вміння, в яких проявляється творчий характер особистості, в цьому і полягає його продуктивність.

Аналіз психолого-педагогічної літератури свідчить про те, що проектувальні вміння розглядалися фахівцями з позиції різних підходів. У дослідженнях учених виявлено роль і місце конструктивно-проективних умінь у діяльності педагога, наведений їх перелік, запропоновані способи вимірювання рівня сформованості, дані рекомендації 3 їх збагачення та розвитку.

О. Жерновникова (2015) зазначає, що конструктивна діяльність складається 3 конструктивно-змістовної (відбір і композиція навчального матеріалу, планування і побудова освітнього процесу); конструктивно- 
оперативної (планування своїх дій і дій учнів) і конструктивно-матеріальної (проектування навчально-матеріальної бази уроку).

Погоджуючись 3 цією позицією, зауважимо, що конструктивна діяльність пов'язана з навчальною роботою і містить такі дидактичні вміння, як: проектування і пов’язане з ним перспективне планування уроків; власне конструювання уроку з урахуванням всіх об’єктивних і суб'єктивних реалій і пов’язане з ним (позаурочне, перспективне) планування.

Отже, проектувальна компетентність складається 3 проектувальних умінь, які характеризуються усвідомленістю, самостійністю, продуктивністю і динамізмом. Їх усвідомленість полягає в тому, що, здійснюючи ту чи іншу дію, суб’єкт усвідомлює мету дії і відповідно керує нею за допомогою сформованих навичок. Його самостійність проявляється в можливості перенесення вміння з однієї діяльності на іншу.

Продуктивність уміння визначається його усвідомленістю, що дозволяє не просто відтворювати засвоєні дії, але і знаходити більш ефективні рішення використання сформованих навичок.

До аналітичних умінь віднесено вміння розчленовувати педагогічні явища на складові елементи (вміти будувати урок; осмислювати кожен його етап; знаходити нові форми і методи представлення нового матеріалу; використовувати індивідуальні стратегії навчання, портфоліо, комп’ютерні тестові завдання, різноманітні інтернет-технології; правильно діагностувати педагогічні явища; проводити рубіжний контроль як необхідну частину бально-рейтингової системи; знаходити і формулювати основні завдання уроку і способи їх оптимального вирішення).

Аналіз наукової літератури дозволяє сформулювати діагностичні вміння майбутнього вчителя, які йому необхідні для проектування освітнього та виховного процесу, а саме: вміння виділяти цілі, форми і види контролю і самоконтролю; планувати і здійснювати поточний, навчальний і підсумковий контроль знань та умінь учнів; об’єктивно і мотивовано оцінювати навчальну діяльність школярів; виявляти проблеми, визначати мету, завдання, методи 
контролю та форми оцінювання результатів навченості; обирати i застосовувати методи та методики вивчення як особистості, так і колективу; мати уявлення про інноваційні технології навчання на різних етапах освіти; організувати експеримент i проводити моніторинг його ефективності; узагальнювати, описувати, оформляти результати науково-методичних досліджень; виявляти об’ єкт вивчення.

Не менш важливими є і такі дослідницькі вміння, як: організувати дослідницький пошук; володіти методикою викладання, методологією дослідницької діяльності; вміти генерувати оригінальні ідеї; методично грамотно розробляти дидактичний інструментарій, індивідуальні освітні маршрути учнів (Нагаєв, Портян, 2017).

Щоб створити певний проект учителю необхідно оволодіти креативними вміннями для розробки персональних портфоліо, створення особливого креативного середовища уроку і позаурочної діяльності, пошуку нових технологій навчання і виховання школярів (Портян, 2015).

Для проектування середовища необхідні і рефлексивні вміння, а саме: аналізувати ефективність педагогічного пошуку; отримувати користь 3 досвіду; мати здатність оцінювати педагогічну дійсність (самооцінка виступає як індикатор рефлексивного самоврядування); продуктивно ставитись до помилок і невдач.

На основі вищезазначеного, виокремимо таку номенклатуру умінь, які сприяють сформованості у майбутніх учителів проектувальної компетентності: аналітичні, гностичні, дослідницькі, діагностичні, креативні, рефлексивні тощо.

Отже, педагогічне проектування розуміємо як: практико-орієнтовану діяльність, метою якої є розробка нових, що не існують у практиці освітніх систем і видів педагогічної діяльності; нову галузь знання; прикладний науковий напрям педагогіки, націлений на вирішення завдань вдосконалення сучасних освітніх систем; спосіб нормування педагогічної та науководослідної діяльності; процес створення і реалізації педагогічного проекту; 
специфічний спосіб розвитку особистості; технологія навчання; засоби навчання (виховання).

Проектування і прогнозування мають спільні цілі і орієнтацію на досягнення результатів. Але разом із тим проектування вимагає більшої відповідальності за отриманий результат, безпосередньо використовуваний на практиці. Взаємовплив проектування та прогнозування полягає в тому, що проектування як дослідницька діяльність є базою для можливого виявлення нових джерел прогнозування.

Прогнозування, як розумова процедура, використовується в проектуванні для обгрунтування можливих станів того чи іншого об'єкта чи явища.

Конструювання та проектування мають спільну основу в тому, що характеризуються послідовністю етапів наближення задуму до його предметної реалізації. У конструюванні присутні елементи проектованого об'єкта, а в проектуванні створюється система взаємозв'язків цих елементів при розробці та оформленні проекту.

Проектування та моделювання взаємообумовлені тим, що моделювання розглядається як теоретичне i практичне оперування об'єктом i широко використовується в проектуванні для створення образу об'єкта, явища або процесу, яких ще немає в реальності. До процедури проектування входить створення моделей (образів) майбутнього, тому моделювання можна вважати частиною проектування.

Розглядаючи «проектування» як уявне і практичне втілення того, що можливо, і того, що має бути, необхідно схарактеризувати спеціальні групи вмінь, якими мають опанувати майбутні вчителі початкової школи та вихователі закладів дошкільної освіти. До таких груп умінь варто віднести:

- ітке визначення цілей і завдань майбутньої діяльності на основі діагностики з метою виявлення проблеми;

- $\quad$ облік рівня володіння навчальним предметом, інтересів, потреб і можливостей учнів та дошкільників; 
- пошук інформації з проблеми, яка вивчається, в науковопедагогічній та методичній літературі;

- $\quad$ визначення змісту, форм, методів і засобів в індивідуальній та колективній діяльності зі школярами та дошкільниками;

- використання системи прийомів стимулювання пізнавальної активності школярів та дошкільників;

• визначення умов сумісної діяльності розробників проекту;

- $\quad$ спільне з іншими учасниками освітнього процесу проектування розвитку креативного середовища.

Сформованість проектувальної компетентності обов’язково має містити рефлексивні, пошукові, менеджерські, комунікативні, презентаційні та організаторські вміння.

Виокремлення вмінь сприяло визначенню структурних компонентів сформованості проектувальної компетентності майбутніх учителів початкової школи та вихователів. До таких компонентів належать: мотиваційно-ціннісний, когнітивний та діяльнісно-рефлексійний. Мотиваційно-ціннісний компонент сформованості передбачає наявність у майбутніх учителів початкової школи і вихователів закладів дошкільної освіти мотивації до навчального проектування, когнітивний - обізнаність зі знаннями, необхідними для сформованості проектувальної компетентності та набуття комплексу відповідних умінь i навичок, що забезпечують оптимізацію освітнього процесу, діяльнісно-рефлексійний - оволодіння вміннями проектувати освітній процес у закладах дошкільної освіти та початковій школі, корекція цього процесу.

До вмінь, які сприяють сформованості проектувальної компетентності віднесено: аналітичні, гностичні, дослідницькі, діагностичні, креативні та рефлексивні. Формування відповідних умінь відбувалося під час вивчення студентами курсів «Методика викладання педагогічних дисциплін», «Організація і управління педагогічним процесом у закладах дошкільної освіти», «Загальна педагогіка». 
У педагогічному експерименті брали участь 92 студенти факультетів початкової та дошкільної освіти Харківського національного педагогічного університету імені Г. С. Сковороди (ЕГ 46 студентів) та (КГ 46 студентів).

3 урахуванням теоретичних аспектів дослідження визначено критерії та показники сформованості в майбутніх учителів початкової школи та вихователів закладів дошкільної освіти проектувальної компетентності мотиваційний (наявність інтересу), когнітивно-інформаційний (наявність сукупності знань), технологічно-діяльнісний (сукупність умінь та навичок проектування майбутньої професійної діяльності), особистісно-рефлексійний (уміння використовувати набуті знання та навички в нових та нестандартних ситуаціях, здійснювати рефлексійний аналіз та корекцію професійної діяльності).

У процесі проведення педагогічного експерименту на констатувальному етапі за допомогою комплексу вимірювальних процедур відповідно до розроблених критеріїв ми досліджували рівень сформованості проектувальної компетентності майбутніх учителів початкової школи і вихователів закладів дошкільної освіти. Зазначимо, що з метою розроблення програми дослідження були обгрунтовані методики: «Діагностика цінностей та мотивів проектної діяльності» (мотиваційний критерій); «Діагностика проектувальних знань, умінь, навичок використання у майбутній професійній діяльності» (когнітивно-інформаційний критерій); «Діагностика рівня технологічної готовності» (технологічно-діяльнісний критерій); «Діагностика рівня особистісно-творчої готовності майбутніх учителів початкової школи та вихователів» (особистісно-рефлексійний критерій).

Розвиток кожного компонента пов'язаний із визначенням його характеристик і властивостей як частини цілісної системи сформованості проектувальної компетентності майбутніх учителів початкової школи i вихователів.

Для перевірки сформованості зазначених компонентів проектувальної компетентності майбутніх учителів початкової школи і вихователів закладів 
дошкільної освіти за визначеними критеріями використовували відповідні методи дослідження. У результаті проведення констатувального етапу педагогічного есперименту, оцінюючи сформованість проектувальної компетентності майбутніх вихователів та учителів початкової школи за мотиваційним критерієм, зазначимо, що переважна більшість студентів у повній мірі не усвідомлюють важливість цієї складової своєї професійної підготовки, а тому i не вмотивовані. Відсутність знань 3 навчального проектування (когнітивно-інформаційний критерій) у майбутніх фахівців привели до несформованості проектувальних умінь та навичок (технологічно-діяльнісний критерій) i невміння здійснювати рефлексію у визначеному контексті (особистісно-рефлексійний критерій).

Отже, результати проведеного етапу педагогічного експерименту дали підстави констатувати переважно середній та низький рівні сформованості проектувальної компетентності майбутніх учителів початкової школи і вихователів закладів дошкільної освіти.

Таблиця

Результати констатувального етапу експериментальної перевірки сформованості проектувальної компетентності майбутніх учителів початкової школи і вихователів закладів дошкільної освіти (у \%)

\begin{tabular}{|c|c|c|c|c|}
\hline Критерії & Показники & 苞 & ЕГ (46 осіб) & КГ (46 осіб) \\
\hline \multirow[t]{3}{*}{ Мотиваційний } & \multirow[t]{3}{*}{ Наявність інтересу } & $\mathrm{B}$ & - & - \\
\hline & & $\mathrm{C}$ & 34,2 & 33,5 \\
\hline & & $\mathrm{H}$ & 65,8 & 66,5 \\
\hline \multirow{3}{*}{$\begin{array}{c}\text { Когнітивно- } \\
\text { iнформаційний }\end{array}$} & \multirow{3}{*}{$\begin{array}{c}\text { Наявність сукупності } \\
\text { знань }\end{array}$} & $\mathrm{B}$ & 11,0 & 9,9 \\
\hline & & $\mathrm{C}$ & 42,0 & 42,3 \\
\hline & & $\mathrm{H}$ & 47,0 & 47,8 \\
\hline \multirow{3}{*}{$\begin{array}{l}\text { Технологічно- } \\
\text { діяльнісний }\end{array}$} & \multirow{3}{*}{$\begin{array}{c}\text { Сукупність умінь та } \\
\text { навичок проектування } \\
\text { майбутньої професійної } \\
\text { діяльності }\end{array}$} & $\mathrm{B}$ & - & - \\
\hline & & $\mathrm{C}$ & 26,8 & 23,6 \\
\hline & & $\mathrm{H}$ & 73,2 & 76,4 \\
\hline $\begin{array}{l}\text { Особистісно- } \\
\text { рефлексійний }\end{array}$ & $\begin{array}{c}\text { Уміння використовувати } \\
\text { набуті знання та навички в }\end{array}$ & $\mathrm{B}$ & - & - \\
\hline
\end{tabular}




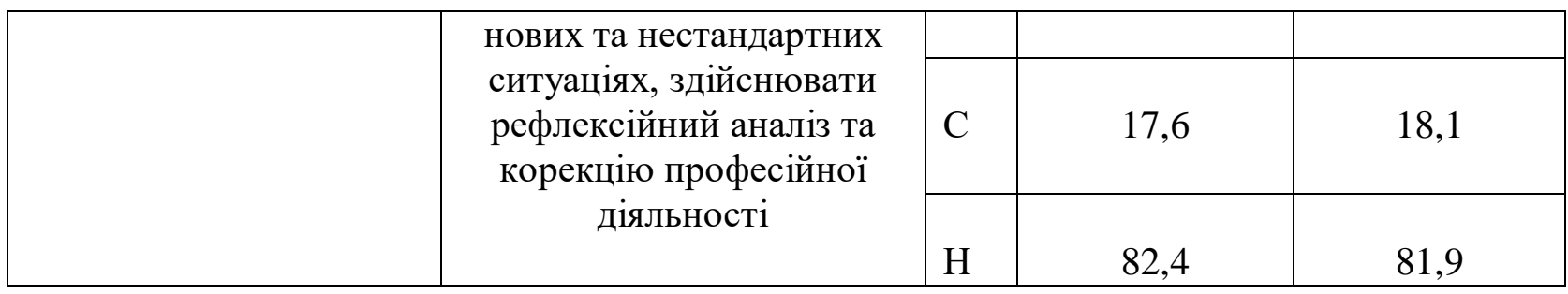

Обговорення. Результати проведеного констатувального етапу педагогічного експерименту дали підстави визначити наступне. За мотиваційним критерієм лише $34,2 \%$ опитаних майбутніх учителів початкової школи і вихователів (ЕГ) та 33,5\% (КГ) мають середній рівень прояву інтересу до формування проектувальної компетентності, всі інші взагалі не вмотивовані. За когнітивно-інформаційним критерієм спостерігається краща ситуація, оскільки 11\% мають високий рівень сформованості відповідних знань (ЕГ) та 9,9\% (КГ), середній 42,0\% (ЕГ) та $42,3(\mathrm{~K} \Gamma)$.

За технологічно-діяльнісним критерієм сукупність умінь та навичок проектування майбутньої професійної діяльності у студентів ЕГ складає 73,2\% низький рівень та 76,4\% в КГ. Найнижчі результати були отримані за особистісно-рефлексійним критерієм - низький рівень сформованості вмінь використовувати набуті знання та навички в нових та нестандартних ситуаціях, здійснювати рефлексійний аналіз та корекцію професійної діяльності мають 82,4\% студентів ЕГ та 81,9 КГ.

Висновки. Отже, проведений аналіз наукової літератури надав підстави стверджувати, що формування проектувальної компетентності майбутніх учителів початкової школи та вихователів закладів дошкільної освіти передбачає створення алгоритмічних приписів для проектування різних об’єктів на основі узагальнених способів педагогічного проектування, діагностики, цілепокладання, володіння симбіозом умінь, які розвиваються в процесі навчання студентів, оформлення документації 3 педагогічної практики, курсових і магістерських проектів. 
Компонентами формування проектувальної компетентності майбутніх учителів початкової школи і вихователів визначено: мотиваційно-ціннісний, когнітивний та діяльнісно-рефлексійний. Критерії за якими відбувалося оцінювання високого, середнього та низького рівнів сформованості проектувальної компетентності студентів були такі: мотиваційний, когнітивно-інформаційний, технологічно-діяльнісний, особистіснорефлексійний.

У процесі проведення констатувального етапу педагогічного експерименту нами було застосовано комплекс діагностичних методів відповідно до кожного із визначених критеріїв та показників, у результаті чого було зроблено висновок про перевагу середнього та низького рівнів сформованості проектувальної компетентності майбутніх учителів початкової школи та вихователів. 3'ясовано, що майбутні вчителі початкової школи та вихователі закладів дошкільної освіти виявили низький рівень оволодіння способами сформованості проектувальної компетентності та неготовність використання ії у майбутній професії.

Перспективи подальших розвідок убачаємо в розробці та експериментальній перевірці технології формування проектувальної компетентності майбутніх учителів початкової школи та вихователів закладів дошкільної освіти.

\section{ЛІТЕРАТУРА:}

Брюханова, Н. О. Основи педагогічного проектування в інженерно-педагогічній освіті : монографія. Х. : НТМТ, 2010.

Брюханова, Н. О. Концептуальні положення проектування системи педагогічної підготовки майбутніх інженерів-педагогів. Проблеми інженерно-педагогічної освіти, 2012. Вип. 34-35, С. 8-13.

Буркіна, Н. В. Проектування методичної системи дистанційного навчання математики у вищих навчальних закладах. (Дис. ... канд. пед. наук). Черкаський державний педагогічний університет імені Богдана Хмельницького, 2009.

Гончаренко, С. Український педагогічний словник. К. : Либідь, 1997.

Гончаренко, Т. Л., Шарко, В. Д. Технології проектування навчального процесу з фізики та підготовка вчителя до їх реалізації. Фізика та астрономія в школі, 2011, № 8, C. 23-26.

Гриньова, В. М. Професійна компетентність учителя: суть, структура, умови формування. Х. : Апостроф, 2011.

Гриньова, М. В. Педагогічні технології: теорія та практика. Полтава : Прометей, 2012. 
Докучаєва, В. В. Теоретико-методологічні засади проектування інноваційних педагогічних систем. (Дис. ... канд. пед. наук). Луганський національний університет імені Тараса Шевченка, 2007.

Жерновникова, О. А. Підготовка майбутнього вчителя до навчального проектування як психолого-педагогічна проблема. Педагогіка та психологія, 2015, Вип. 49, С. $193-$ 202.

Зязюн, І. А. Дидактичне проектування технологій і методів учіння у вимірах педагогічної дії. Витоки педагогічної майстерності, 2010, Вип. 7, С. 63-73.

Коберник, О. М. Проектування навчально-виховного процесу в школі. К. : Хрещатик, 1995.

Коляда, М. Г. Загальні принципи педагогічного проектування і діяльнісний підхід до його реалізації. Проблеми сучасної педагогічної освіти, 2006, № 12, С. 95-101.

Коханко, О. Г. Формування у студентів знань і вмінь проектування уроку на засадах матрично-модульного підходу. К. : Національний педагогічний університет імені М. П. Драгоманова, 2009.

Кравець, О. С. Теоретичні засади адаптивного підходу у використанні технології проектування навчальної інформації викладачем вищого навчального закладу. Вісник Житомирського державного університету імені Івана Франка, 2013, Вип. 6, С. 126-130.

Нагаєв, В. М., Портян, М. О. Методика викладання у вищій школі. Харків. Колегіум, 2017. Портян, М.О. Обгрунтування технології формування ділових якостей студентів. Педагогіка та психологія, 2015, Вип. 50, С. 110-119.

Пуліна, А. А. Метод проектів: історія й перспективи розвитку в сучасній системі освіти. Педагогічні наук, 2005, Вип. 40, С. 116-119.

Солом'яний, О. М. Педагогічне проектування як складова професійної діяльності викладача вищої школи. Наука і освіта, 2006. № 3-4, С. 130-132.

Цимбалару, А. Д. Педагогічне проектування освітнього простору в школі I ступеня: теорія і практика. К. : Педагогічна думка, 2013.

Юр’єва, К. А., Тіщенко, О. М. Компетенція, компетентність, міжкультурна компетентність учителя: сутність і зміст. Засоби навчальної та науково-дослідної роботи, 2014, Вип. 42, С. 169-182. http://oaji.net/articles/2014/982-1414764151.pdf

Ярошинська, О. О. Проектування освітнього середовища професійної підготовки майбутніх учителів початкової школи. Умань : ФОП Жовтий О. О., 2014.

Quinn, C. Getting down to business : Engaging students through innovative project designs. Selections. 36-th International Annual Conference, 2002, P. 107-108.

\section{REFERENCES:}

Briukhanova, N. O. (2010). Osnovy pedahohichnoho proektuvannia v inzhenerno-pedahohichnii osviti [Fundamentals of the pedagogical designing in engineering and pedagogical education] : monohrafiia. Kharkiv : NTMT (in Ukrainian).

Briukhanova, N. O. (2012). Kontseptualni polozhennia proektuvannia systemy pedahohichnoi pidhotovky maibutnikh inzheneriv-pedahohiv. [Conceptual provisions for designing a system of pedagogical training for future engineer educators]. Problemy inzhenernopedahohichnoi osvity, 34-35, 8-13 (in Ukrainian).

Burkina, N. V. (2009). Proektuvannia metodychnoi systemy dystantsiinoho navchannia matematyky u vyshchykh navchalnykh zakladakh. [Designing a methodical system of distance learning of mathematics in higher educational institutions]. (Candidate's thesis). Cherkaskyi derzhavnyi pedahohichnyi universytet imeni Bohdana Khmelnytskoho, Cherkasy, Ukraine (in Ukrainian).

Honcharenko, S. (1997). Ukrainskyi pedahohichnyi slovnyk [Ukrainian Pedagogical Dictionary]. Kyiv: Lybid (in Ukrainian). 
Honcharenko, T. L., Sharko, V. D. (2011).Tekhnolohii proektuvannia navchalnoho protsesu z fizyky ta pidhotovka vchytelia do yikh realizatsii. [Technologies for designing the educational process in the physics and preparing a teacher for their implementation]. Fizyka ta astronomiia v shkoli, 8, 23-26 (in Ukrainian).

Hrynova, V. M. (2011). Profesiina kompetentnist uchytelia: sut, struktura, umovy formuvannia. [Professional competence of the teacher: essence, structure, conditions of formation.]. Kharkiv: Apostrof (in Ukrainian).

Hrynova, M. V. (2012). Pedahohichni tekhnolohii: teoriia ta praktyka. [Pedagogical Technologies: Theory and Practice.]. Poltava : Prometei (in Ukrainian).

Dokuchaieva, V. V. (2007). Teoretyko-metodolohichni zasady proektuvannia innovatsiinykh pedahohichnykh system. [Theoretical and methodological principles of designing innovative pedagogical systems]. (Candidate's thesis). Luhanskyi natsionalnyi universytet imeni Tarasa Shevchenka, Luhansk, Ukraine (in Ukrainian)

Zhernovnykova, O. A. (2015). Pidgotovka majbutn'ogo vchitelya do navchal'nogo proektuvannya yak psihologo-pedagogichna problema. [Preparation of the future teacher for educational design as a psychological and pedagogical problem]. Pedagogika ta psihologiya, 49, 193-202 (in Ukrainian).

Ziaziun, I. A. (2010). Dydaktychne proektuvannia tekhnolohii i metodiv uchinnia u vymirakh pedahohichnoi dii. [Didactic design of technologies and methods of teaching in measures of pedagogical action.]. Vytoky pedahohichnoi maisternosti, 7, 63-73 (in Ukrainian).

Kobernyk, O. M. (1995). Proektuvannia navchalno-vykhovnoho protsesu v shkoli. [Design of educational process in school]. Kyiv : Khreshchatyk (in Ukrainian).

Koliada, M. H. (2006). Zahalni pryntsypy pedahohichnoho proektuvannia i diialnisnyi pidkhid do yoho realizatsii. [General principles of pedagogical design and activity approach to its realization]. Problemy suchasnoi pedahohichnoi osvity, 12, 95-101 (in Ukrainian).

Kokhanko, O. H. (2009). Formuvannia u studentiv znan i vmin proektuvannia uroku na zasadakh matrychno-modulnoho pidkhodu. [Formation of the students knowledge and skills of designing the lesson on the basis of the matrix-modular approach]. (Candidate's thesis). Natsionalnyi pedahohichnyi universytet imeni M. P. Drahomanova, Kyiv, Ukraine (in Ukrainian).

Kravets, O. Ye. (2013). Teoretychni zasady adaptyvnoho pidkhodu u vykorystanni tekhnolohii proektuvannia navchalnoi informatsii vykladachem vyshchoho navchalnoho zakladu. [Theoretical principles of an adaptive approach to the use of technology for designing educational information by a teacher of a higher educational institution]. Visnyk Zhytomyrskoho derzhavnoho universytetu imeni Ivana Franka, 6, 126-130 (in Ukrainian).

Nagaev, V. M., Portyan, M. O. (2017). Metodika vykladannya u vishchij shkoli. [Teaching method in high school]. Harkiv. Kolegium (in Ukrainian).

Portian, M. O. (2015). Obhruntuvannia tekhnolohii formuvannia dilovykh yakostei studentiv. [Justification of the technology of forming the business qualities of students]. Pedahohika ta psykholohiia, 50, 110-119 (in Ukrainian).

Pulina, A. A. (2005). Metod proektiv: istoriia y perspektyvy rozvytku v suchasnii systemi osvity. [Method of projects: history and prospects of development in the modern educational system]. Pedahohichni nauky, 40, 116-119 (in Ukrainian).

Solom'ianyi, O. M. (2006). Pedahohichne proektuvannia yak skladova profesiinoi diialnosti vykladacha vyshchoi shkoly. [Pedagogical design as a component of the professional activity of a teacher of higher education]. Nauka i osvita, 3-4, 130-132 (in Ukrainian).

Tsymbalaru, A. D. (2013). Pedahohichne proektuvannia osvitnoho prostoru v shkoli I stupenia: teoriia i praktyka. [Pedagogical Design of Educational Space in School I Degree: Theory and Practice]. Kyiv : Pedahohichna dumka (in Ukrainian).

Yurieva, K. A., Tishchenko, O. M. (2014). Kompetentsiia, kompetentnist, mizhkulturna kompetentnist uchytelia: sutnist $\mathrm{i}$ zmist. [Competence, competence, intercultural 
competence of the teacher: essence and content]. Zasoby navchalnoi ta naukovodoslidnoi roboty, 42, 169-182. Retrieved from http://oaji.net/articles/2014/9821414764151.pdf. (in Ukrainian).

Yaroshynska, O. O. (2014). Proektuvannia osvitnoho seredovyshcha profesiinoi pidhotovky maibutnikh uchyteliv pochatkovoi shkoly. [Designing an educational environment for the training of future primary school teachers]. Uman : FOP Zhovtyi O. O. (in Ukrainian).

Quinn, C. (2002). Getting down to business : Engaging students through innovative project designs. Selections. 36-th International Annual Conference, 2002, 107-108.

\begin{tabular}{lll}
\hline Портян Марина Олександрівна: ORCID: & Portyan Maryna Oleksandrivna: ORCID: \\
http://orcid.org/0000-0001-9399-868X, & http://orcid.org/0000-0001-9399-868X, PhD \\
кандидат педагогічних наук, доцент & in Pedagogy, Associate Professor of the \\
кафедри початкової, дошкільної та & $\begin{array}{l}\text { Department of Preschool, Elementary and } \\
\text { професійної о освіти Харківського }\end{array}$ Vocational Education of H. S. Skovoroda \\
національного педагогічного університету & Kharkiv National Pedagogical University, \\
iмені Г. С. Сковороди, вул. Валентинівська, & Valentynivska Str, Kharkiv, Ukraine 61000 \\
2, Харків, Україна 61000 & \\
e-mail: portyanmarina@gmail.com & e-mail: portyanmarina@gmail.com
\end{tabular}

Цитуйте цю статтю як: Портян М.О. Формування проектувальної компетентності майбутніх учителів початкової школи і вихователів закладів дошкільної освіти. Теорія та методика навчання та виховання. 2019. № $46 . \quad$ С. 104-121. DOI: $10.34142 / 23128046.2019 .46 .08$

Дата надходження статті до редакції: 02.04.2019

Стаття прийнята до друку: 16.04.2019 